\title{
The Impact of $360^{\circ}$ Supply Chain Integration on Operational and Business Performance
}

\author{
D. Chatzoudes ${ }^{1^{*}}$, P. Chatzoglou ${ }^{2}$ \\ Department of Production and Management Engineering, Faculty of Engineering, \\ Democritus University of Thrace, Greece \\ ${ }^{1}$ dchatzoudes@yahoo.gr, ${ }^{2}$ pchatzog@pme.duth.gr
}

\begin{abstract}
Supply chain integration has been a topic of significant academic interest in the operational research discipline for the last few decades. Several scientists have conducted surveys investigating its relationship with operational and / or business performance. The present paper aims to explore supply chain integration on a 360 degree radius, thus, suggesting a Conceptual Framework that accounts for all aspects that have been neglected by most researchers. The introduction of the terminology " $360^{\circ}$ supply chain integration" is being attempted on the basis of a literature review that accumulated measures and concepts used in the past into a holistic Conceptual Framework that aims to provide a guideline towards integrating the supply chain processes of a company. The examination of the proposed Conceptual Framework was made with the use of a structured questionnaire. The questionnaire was distributed to a group of Greek manufacturing companies. The empirical data were analyzed using the "Structural Equation Modelling" technique. Results offer both theoretical and empirical evidence.
\end{abstract}

Keywords: supply chain management, $360^{\circ}$ supply chain integration, structural equation modelling, Greece

\section{Introduction}

The concept of supply chain integration (collaboration) has been emerging in the general management literature and the supply management research over the last 20 years (Andraski, 1998; Heiman and Nickerson, 2002; Singh and Power, 2009). The potential of supply chain collaboration as a business competitive strategy have been explored in the supply chain literature since the first steps of its development (Bowersox, 1990). Nowadays, supply chain integration is considered to be of significant importance by both academics and practitioners and has fully emerged as a dominant theme in the supply chain management (SCM) literature (Burt et al., 2003; Handfield and Nichols, 2002; Horvath, 2001).

During the last twenty years, scholars have agreed that SCM should include the integration of trading partners as a focal point in its development (Barratt and Oliveira, 2001; Pramatari, 2007). According to Bowersox et al. (2000), companies should cooperate so as to achieve common goals and obtain specific benefits. Anderson and Lee (1999) argue that company collaboration and supply chain integration are based on the idea of sharing plans and operational strategies in order to achieve synchronized supply chains. Anthony (2000) describes supply chain collaboration as the procedure in which two or more companies are exchanging information about management, planning, operations and performance measurement.

The growing interest towards the integration of the supply chain is fuelled by a significant number of empirical studies that underline the numerous useful outcomes that can derive from aligning

*Corresponding Author 
objectives and integrating recourses across organizational boundaries (Cetindamar et al., 2005). The literature has investigated such efforts under different names, such as supply chain collaboration, strategic alliances, industrial networks, and inter-firm integration (Cetindamar et al., 2005; Pramatari, 2007; Singh and Power, 2009).

Supply chain integration is considered to enable companies to reduce inventory fluctuations, become more responsive to market turbulence, thus, dealing successfully with the negative impact of the "bullwhip effect" (Chen et al., 2000) that threatens almost all organisations (Holweg et al., 2005). Moreover, studies including comparative data reveal that highly integrated supply chains assist companies in building competitive advantages over rival companies with less collaborative supply chains (Myhr and Spekman, 2005; Themistocleous et al., 2004). Moreover, various cross-sectional studies indicate that collaboration in the supply chain function has a positive impact on financial performance (Vickery et al., 2003; Wisner, 2003). Considering all the above, it is not a coincidence that highly successful organizations (both operationally and financially), such as Dell, HP and Wal-Mart have established solid collaboration structures with their trading partners (Landry, 2003; Magretta and Dell, 1998). Finally, according to various scholars (Heikkila, 2002; Mendelson and Pillai, 1999), supply chain integration is essential in handling the uncertainty and the complexity that characterize the economy of the $21^{\text {st }}$ century.

However consistent and thorough, the supply chain management literature has failed to create a supply chain integration model that goes beyond collaboration with other organisations (Rosenzweig et al., 2003). Authors have spent a lot of effort trying to investigate external integration, thus, failing to introduce into their analysis the integration of internal entities that might have a significant impact on the operational performance (e.g. collaboration between marketing and manufacturing).

In the present study, the definition of supply chain integration takes into consideration the crossbusiness relationships (downwards with suppliers and upwards with distributors and customers) (Frohlich and Westbrook, 2001), but, moreover, includes the degree of strategic internal integration (Rosenzweig et al., 2003). According to theoretical arguments (Handfield and Nichols, 1999), only such a complete view of supply chain integration may lead companies into building a sustainable competitive advantage.

The main purpose of the present study is the creation and verification of a conceptual framework that includes all aspects of supply chain integration, even those that have been neglected by most researchers. The conceptual framework that was developed adopts a holistic approach, sheds light in areas rarely investigated and leads to interesting practical implications.

The following section includes the presentation of the proposed hypotheses of the present study, while in the third section the research methodology is being presented. Results and conclusions are discussed in the sections 4 and 5 respectively.

\section{The Conceptual Framework of the Study}

The present study introduces a newly developed conceptual framework that investigates the relationship between supply chain integration and two measures of business success: operational performance and business performance.

In more detail, the conceptual framework of the study examines causal relationships between five (5) research variables (constructs):

(a) Supplier integration (independent variable),

(b) Internal integration (independent variable),

(c) Customer integration (independent variable),

(d) Operational performance (dependent variable),

(e) Business performance (dependent variable).

The proposed conceptual framework is based on the synthesis of various previous studies (Beamon, 1999; Frohlich and Westbrook, 2001; Narasimhan and Kim, 2002; Rosenzweig et al., 2003; Singh and Power, 2009). To the best of the researchers' knowledge, such a framework has never been introduced to the supply chain management literature before.

The hypotheses of the study are presented below.

\subsection{Supply chain integration and business success}

As already mentioned, the present study adopts a wide definition of supply chain integration. Besides measuring company integration with suppliers and 
customers (a concept acknowledged by the SCM literature), integration between organisational entities is, moreover, introduced to the proposed conceptual framework. The following paragraphs discuss the relationship between the three independent variables and the two measures of business success.

\subsubsection{Supplier integration and operational performance}

The general definition of supplier integration (downward integration) is synonymous with the involvement of suppliers into the productive procedure of another company (Holweg et al., 2005). The goal is the optimal coordination of demand and supply (Singh and Power, 2009). According to Trent and Monczka (1998), supply integration is largely achieved through the coordination of information technologies and the flow of data from customers to suppliers (Trent and Monczka, 1998). Moreover, according to Yao et al. (2007), supplier integration has to do with data flow between two or more companies and constitutes a way towards achieving process integration, under which the supplier actually takes control over the inventory and purchasing functions of the buyer. As it is evident from all the above, the SCM literature has really focused on the role of Information Technologies (IT) in the coordination of the supply chain (Mentzer et al., 2001; Jayaram and Vickery, 1998).

Nevertheless, the supply chain integration of two or more companies and the consequent collaboration does not always guarantee the success of the whole endeavour. The rationale for closely cooperating with suppliers and introducing them to the operational function of a company needs to be persistently planed, actually needed and be beneficial for all involving parties (Bowersox et al., 2000). Singh and Power (2009) argue that building a cooperative relationship with suppliers does not necessarily lead to expected benefits, until the extend and the nature of the cooperation has been thoroughly investigated, discussed, decided and, finally, accepted by all participants.

According to Kaufman et al. (2000), the nature of the cooperation with suppliers can be either "relational" (informal, mutual relationship) or "contractual" (formal, codified relationship). Experience has proved that most companies tend to follow the "relational" model, but recent data (e.g. e-auctions) has shown that the "contractual" model is making a last minute comeback (Singh and Power, 2009).

In order to achieve successful supplier integration, various systems, administrative procedures and ideas should be put in place (Claro et al., 2003; Garcia-Dastugue and Lambert, 2003; Singh and Power, 2009): (a) a transparent and effective communication system should be enabled, (b) suppliers should be involved in new product and target development, (c) common organisational culture should be shared, (d) products should meet quality and time requirements, (e) problems should be solved jointly and $(\mathrm{g})$ benefits should be shared equally among integrating entities.

It is hypothesised that the actual implementation of all the above should have a significant positive impact on the operational performance of a company (Ragatz et al., 1997; Singh and Power, 2009):

Hypothesis 1a: A high degree of supplier integration has a positive impact on operational performance.

\subsubsection{Internal integration and operational performance}

Internal supply chain integration is a concept that has been wrongfully left out of the contemporary SCM literature (Rosenzweig et al., 2003). Even established authors, such as Frohlich and Westbrook (2001), failed to include internal integration into their body of work, only arguing that the broadest "arc of integration" is the one including both suppliers and customers. However, according to qualitative data gathered by Fawcett and Magnan (2002), supply chain managers believe that internal (crossfunctional) integration is at the crux of all supply chain initiatives. Moreover, the relative low scores for internal integration found in the above study highlight the difficulty of companies in knocking down the walls that deteriorate collaboration at a cross-functional level (Fawcett and Magnan, 2002). According to anecdotal accounts from experienced practitioners, internal integration is a first step towards achieving supply chain integration (Handfield and Nichols, 1999; Narasimhan and Kim, 2002; National Research Council, 2000; Swink et al., 2002). 
The supply chain integration construct developed in the present study is based on the argument that the measurement of supply chain integration can only be complete until internal integration is also accounted for. Under that view, the present study extends previous empirical efforts (Rosenzweig et al., 2003) and attempts to introduce the terminology " $360^{\circ}$ supply chain integration" as a concept that is supposed to fully capture the supply chain integration idea.

Although internal supply chain integration has not been a focal point of empirical SCM investigation, various studies argue that it is a concept highly associated with information sharing (Fawcett and Magnan, 2002; Narasimhan and Kim, 2002; Rosenzweig et al., 2003). Since information sharing is a part of all SCM definitions (Antony, 2000 ), it would be logical to assume that internal integration is based on the same principles as the well accepted concepts of supplier and customer integration (external integration). Therefore, internal supply chain integration could be regarded as an integrated part of the supply chain integration construct proposed in the present study.

The impact of internal integration on supply chain performance has never been investigated, to the best of the researchers' knowledge, in the SCM literature. Despite that, one could argue that since it has the same basic characteristics as supplier and customer integration (it is an information intensive procedure), it would produce similar positive effects in the operational performance of a company. Hence, it is hypothesised:

Hypothesis 1b: A high degree of internal integration has a positive impact on operational performance.

\subsubsection{Customer integration and operational performance}

Any practitioner in the field of SCM, whatever how experienced, would argue that the importance of having strong relationships with customers is clear as spring water. Having in mind that satisfaction is considered to be the main driver for business success in the new economy, one could argue that keeping customers satisfied would ensure the economic success of the organisation (Singh and Power, 2009). Of course, this would have been the case if all companies had direct access to the end users of their products. Nowadays, actually a very small segment of manufacturing companies have such a luxury (Bowersox et al., 2000). For most firms, the reality is that the "customer" is a channel in the distribution system that is charged with the task to navigate the product to the ultimate user. Under these circumstances, temporal factors become critical in managing effectively the channel of product distribution (Forrester, 1961; Holmstrom et al. 2002). As an inevitable result, most manufacturing companies concentrate on developing specific systems that deal with these groups of customers (Singh and Power, 2009).

Customer Relational Management (CRM), collaboration in the flow of products (demand planning and replenishment) and shared distribution systems are three of the most popular management systems that have been proposed for dealing with the practical issues of customer collaboration (Singh and Power, 2009; Themistocleous et al., 2004). As in the case of downward integration (supplier integration), the use of shared Information Systems (IT) have been chosen as the most efficient way to help collaborating companies to excel in speed and efficiency (Sanders and Premus, 2005). Moreover, building relations in which forecasts and problems are openly discussed and risks and consequent rewards are commonly shared, have been among the most popular alternatives to IT infrastructure collaboration (Holmstrom et al., 2002; Stank et al., 2001).

The literature recognises the following drivers for successfully integrating customers into the supply chain and, thus, obtaining corresponding benefits (El Sawy et al., 1999; Sabath and Whipple, 2004; Singh and Power, 2009): (a) putting in place formal systems that aim to increase customer satisfaction, (b) always being aware of customer requirements and specifications, (c) having a systematic way to constantly measure customer satisfaction and locate areas of further improvement, (d) paying attention to customer feedback and incorporate suggestions into processes, products and services and (e) always being ready to handle complaints and gain from the problem solving procedure.

It would be expected that companies with such an orientation would excel in managing the supply chain (lower inventory and manufacturing cost, low 
shipping errors, less customer complaints, less backorders, rapid customer response time, etc). Thus, it is hypothesised:

Hypothesis 1c: A high degree of customer integration has a positive impact on operational performance.

\subsubsection{Integration intensity and business performance}

According to the transaction cost theory, a company decides between two organisational forms: market (the price system is the one that controls the flow of products and services between different companies) and hierarchy (products and services are produced and traded inside one organisational structure) (Williamson, 1981). Therefore, every different activity of the value chain should be executed inside the borders of the organisation and not being let to be formed by the market, when its management through the corporate hierarchy is more productive from the one of the market (Williamson, 1991).

Companies that operate under the market paradigm and are highly integrated (downwards, internally, and upwards) may reduce the transaction cost in three ways (Dyer, 1997; Williams et al., 2002): (a) through long term cooperation, supply chain entities have enough opportunities to correct any transaction inefficiencies, (b) extensive information sharing between companies of the same value chain may increase the quality of information and subsequently reduce the potential for opportunism from both sides, (c) the use of non-contractual agreements that are based on experience and mutual trust developed over time may reduce the cost of maintaining more traditional, legal contracts.

Through an efficient governance structure, highly integrated companies can reduce the transaction cost significantly. The reduction of the transaction cost, subsequently leads in reduction in the unit production cost. Therefore, the company may improve its financial performance. Hence, we hypothesise:

Hypothesis 2a: A high degree of supplier integration has a positive impact on business performance.

Hypothesis 2b: A high degree of internal integration has a positive impact on business performance.

Hypothesis 2c: A high degree of customer integration has a positive impact on business performance.

\subsection{Correlation between supply chain integration constructs}

As stated above, all three supply chain integration constructs of the present study (supplier integration, internal integration, customer integration) can be fully utilised by using, more or less, the same recourses and capabilities: (a) culture towards collaboration, (b) sharing of information and (c) adequate technology systems that help in facilitating the communication between different business entities (e.g. Information Systems).

Since skills sets, management systems and technologies required for supplier, customer and internal interactions are quite similar to one another, one could, for example, expect that firms that would be strong on collaborating with suppliers will be also strong in customer and internal integration (Singh and Power, 2009). Therefore, the following hypothesis is formulated:

Hypothesis 3: Supplier integration, internal integration and customer integration are positively related to one another.

Figure 1 Summarizes all the above hypotheses, thus, presenting the proposed Conceptual Framework of the study.

Figure 1. The Proposed Conceptual Framework of the Study

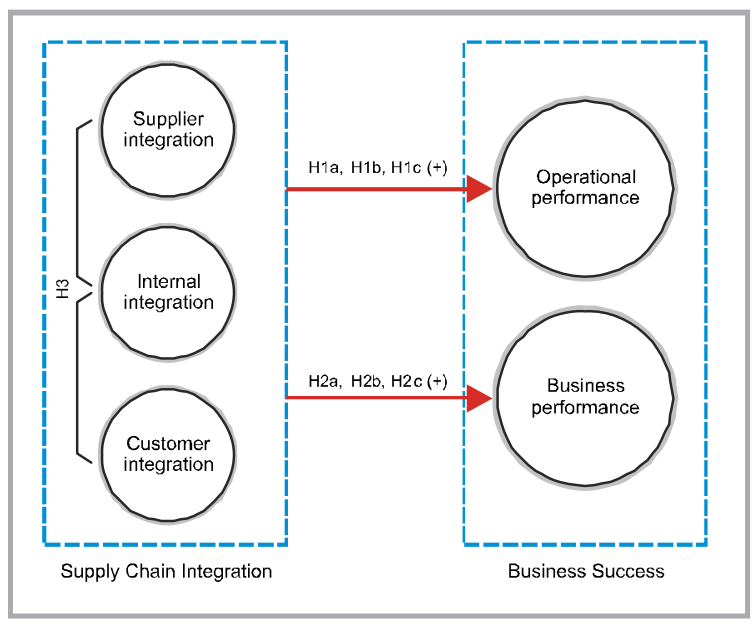

\section{Research Methodology}

\subsection{Sample of the study}

The proposed conceptual framework of the present study was tested with the use of a newly developed questionnaire on a sample of Greek manufacturing 
companies. The Greek industry, as most sectors of the Greek economy, is characterised by the small company size, since only $2 \%$ of companies have more that 500 employees (ICAP, 2004). The target population consists of 5.293 manufacturing companies that were included in the special edition of ICAP (2007) entitled "Greek Financial Guide 2007". ICAP is a Greek consultant organisation that is considered to be a reliable source for data of Greek companies. The necessary contact information about companies of the sample were, also, obtained from the official site of ICAP (www.icap.gr).

\subsection{Measures}

The measurement of each of the five variables (constructs) of the present study was conducted with the use of multiple items (questions) that were adopted from the international literature, while few questions were constructed by the research team. All items were translated to Greek and then back to English by another person, so the detection and consequent improvement of any discrepancies was possible. The five point Likert scale was used for the measurement of all variables.

The complete form of the questionnaire used in the survey consisted of six units. The first five were used for the measurement of the five study variables, while the sixth unit included demographic questions about the person filling the questionnaire and the company of his employment. The measurement of the five study variables included 58 questions (see also Table 1 for extensive details):

A. Supplier integration (13 items): The measurement of supplier integration was made with the use of 13 items that have been previously utilised in the studies of Singh and Power (2009), Narasimhan and Kim (2002), Frohlich and Westbrook (2001), Carr and Pearson (1999) and Stevens (1989).

B. Internal integration (10 items): The measurement of internal integration was made with the use of 6 items used by Narasimhan and Kim (2002), while 4 questions were newly developed and formulated after an extensive literature review.

C. Customer integration (13 items): The measurement of customer integration was made with the use of 13 items that have been previously utilised in the studies of Singh and Power (2009),
Narasimhan and Kim (2002) and Frohlich and Westbrook (2001).

D. Operational performance (16 items): The measurement of operational performance was made with the use of two sub-factors and 16 items previously used in the study of Frohlich and Westbrook (2001). Both sub-factors (productivity and non-productivity performance) were measured with the use of 8 items each.

E. Business performance (6 items): The measurement of business performance was made with the use of a representative sample of financial and nonfinancial indicators based on the Balanced Scorecard (Kaplan and Norton, 1992). Three items were used for capturing the financial perspective, one question for capturing the customer perspective and, finally, two questions for capturing the learning and growth perspective. The same method of measurement has been utilised in the study of Rosenzweig et al. (2003).

\subsection{Data collection}

The final questionnaire and a cover letter including all necessary clarifications, were sent to the production directors of the companies of the sample. Production directors were selected as the key respondents due to their experience and knowledge of the field. Moreover, it was strongly suggested by the members of the research team that the Chief Financial Officer (CFO) of the company should be consulted during the completion of the fifth part of the questionnaire (business performance measurement).

Questionnaires were sent only after telephonic contact with the production director in each company has been established. In order to send the questionnaire and the necessary clarifications to the person contacted by telephone, fax, traditional mail, or electronic mail services were utilized.

After making all necessary telephone calls, 416 questionnaires were distributed to the 416 companies that agreed to participate in the survey. The research period lasted four months (January to June 2010). Totally, 136 questionnaires were returned, and after conducting all necessary controls 132 were used for data analysis (data analysis was conducted with the use of the statistical packages S.P.S.S. 14.0 and Lisrel 8.74). The 132 returned questionnaires represent a very satisfactory response rate of $31,7 \%$. 
Chatzoudes and Chatzoglou: The Impact of $360^{\circ}$ Supply Chain Integration on Operational and Business Performance

Table 1. The measurement of the variables of the study

\begin{tabular}{|c|c|}
\hline Variables & Item description \\
\hline Supplier integration & $\begin{array}{l}\text { 1. The organization seeks long-term stable relationships with suppliers. } \\
\text { 2. The organization has built strategic partnerships with suppliers. } \\
\text { 3. Suppliers are consulted when values of the organization are being developed. } \\
\text { 4. The organization seeks assurance of quality from suppliers. } \\
\text { 5. Suppliers are provided with information so that they can improve their quality and responsiveness. } \\
\text { 6. Information exchange with suppliers through Information Technology systems is a method commonly used. } \\
\text { 7. Suppliers participate in the design stage and development of new products. } \\
\text { 8. Quick ordering systems with main suppliers have been established. } \\
\text { 9. Stable procurement through supplier networks is being achieved. } \\
\text { 10. The participation level of suppliers in the process of procurement and production is high. } \\
\text { 11. Production plans with main suppliers are being shared. } \\
\text { 12. Packaging customization with main suppliers is being achieved. } \\
\text { 13. The gains resulting from cooperation with suppliers are equally shared. }\end{array}$ \\
\hline Internal integration & $\begin{array}{l}\text { 1. Cross-functional management is extensively used. } \\
\text { 2. Cross-functional integration is very significant for all supply chain initiatives. } \\
\text { 3. The cooperation with the marketing department is constant and successful. } \\
\text { 4. The production department is always aware of the strategic plans of the company. } \\
\text { 5. Periodic interdepartmental meetings among internal functions are commonly utilised. } \\
\text { 6. Sharing of information inside the organisation is extensive. } \\
\text { 7. Data integration among internal functions is achieved through the use of Information Technology systems. } \\
\text { 8. Integrative inventory management is being implemented. } \\
\text { 9. Real-time searching of the level of inventory is being implemented. } \\
\text { 10. The rate of data integration in production process is high. }\end{array}$ \\
\hline Customer integration & $\begin{array}{l}\text { 1. The level of computerization for customer ordering is quite high. } \\
\text { 2. The level of sharing of market information with customers is quite high. } \\
\text { 3. Market information with customers is being shared through the use of Information Technology systems. } \\
\text { 4. Periodic customer meetings are commonly utilised. } \\
\text { 5. The organization is aware of the requirements of its customers. } \\
\text { 6. The organization measures customer satisfaction. } \\
\text { 7. Processes and activities of the organization are designed to increase customer satisfaction levels. } \\
\text { 8. Customers are encouraged to provide feedback. } \\
\text { 9. The company is actively seeking feedback from customers. } \\
\text { 10. The feedback provided by customers is used to improve customer relations, processes, products and services. } \\
\text { 11. The organization has systematic processes for handling complaints. } \\
\text { 12. Misunderstandings between customers and organization about orders are rare. } \\
\text { 13. Customers contribute to the development of the organizational values. }\end{array}$ \\
\hline
\end{tabular}




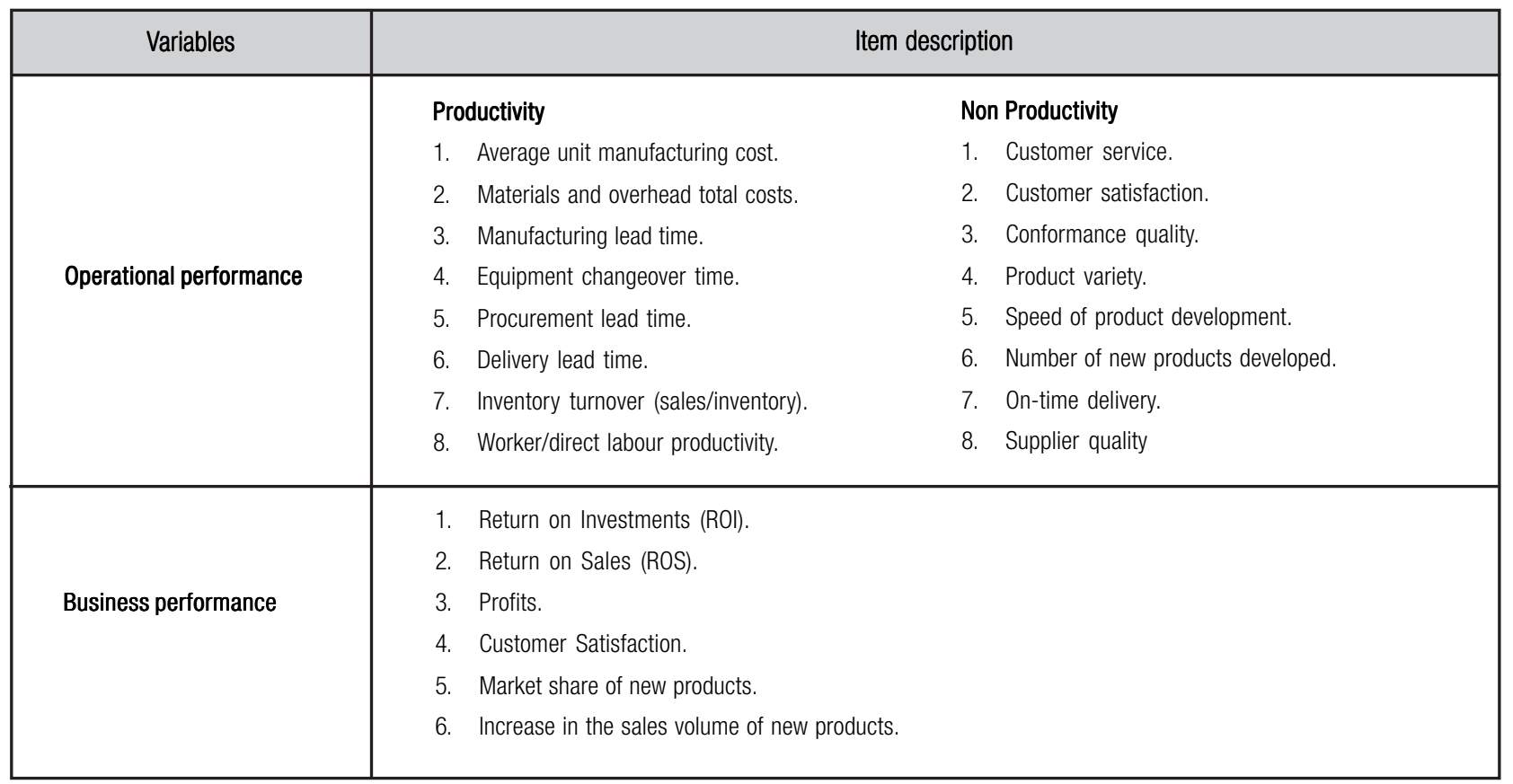

\subsection{Reliability and validity}

The instrument that was used in the present study was tested for both its content and construct validity. The content validity test was conducted prior to the beginning of the survey and included: (a) consultation with academics of the field, (b) consultation with experienced practitioners, and (c) pilot testing. The construct validity test was conducted in two steps. Each of the five research variables was evaluated (a) for its unidimensionality and reliability, (b) for the goodness of fit to the proposed research model.

The estimation of the unidimensionality of each of the five variables was conducted using Explanatory Factor Analysis (EFA) with the method of Principal Component Analysis. Moreover, for the estimation of the reliability of the research variables, the statistical measure Cronbach Alpha was used (the statistical package S.P.S.S. was used in both cases). All tests concluded that all the scales used, after the extraction of various items (when needed), are valid and reliable (see Table 2 below for the main results).

Furthermore, the evaluation of the goodness of fit of each of the five research variables to the proposed model was conducted using Confirmatory Factor Analysis (CFA), with the use of the statistical package LISREL 8.74. The CFA did not include items
Table 2. Estimation of unidimensionality and reliability

\begin{tabular}{|l|c|c|c|c|c|}
\hline Variables & $\begin{array}{c}\text { Kaiser - } \\
\text { Mayer - } \\
\text { Olkin }\end{array}$ & $\begin{array}{c}\text { Bartlett's } \\
\text { Test of } \\
\text { Sphericity }\end{array}$ & $\begin{array}{c}\text { Eigen - } \\
\text { value }\end{array}$ & Variance & $\begin{array}{c}\text { Cronbach } \\
\text { Alpha }\end{array}$ \\
\hline $\begin{array}{l}\text { Supplier } \\
\text { integration } \\
\text { Internal }\end{array}$ & 0,716 & $122,3^{*}$ & 2,151 & $76,94 \%$ & 0,88 \\
$\begin{array}{l}\text { integration } \\
\text { Customer } \\
\text { integration } \\
\text { Operational } \\
\text { performance } \\
\text { Business } \\
\text { performance }\end{array}$ & 0,731 & $79,3^{*}$ & 2,569 & $78,63 \%$ & 0,813 \\
\hline
\end{tabular}

${ }^{*} p<0,01$

that were excluded during the EFA (see Table 3 below for the main results).

All tests concerning the estimation of the goodness of fit to the proposed model produced satisfactory results. Finally, after the successful completion of the construct validity test of the questionnaire, the final score of each variable was calculated using the mean of the items used in each case. 
Table 3. Estimation of the goodness of fit

\begin{tabular}{|c|c|c|c|c|c|c|}
\hline Variables & $x^{2}$ & C.R. & V.E. & RMSEA & $\mathrm{CFI}$ & $\mathrm{GFI}$ \\
\hline $\begin{array}{l}\text { Supplier } \\
\text { integration }\end{array}$ & $63,46^{\star}$ & 0,76 & $63 \%$ & 0,096 & 0,96 & 0,93 \\
\hline $\begin{array}{l}\text { Internal } \\
\text { integration }\end{array}$ & $25,64^{*}$ & 0,81 & $69 \%$ & 0,067 & 0,98 & 0,97 \\
\hline $\begin{array}{l}\text { Customer } \\
\text { integration }\end{array}$ & $19,65^{\star}$ & 0,79 & $71 \%$ & 0,095 & 0,96 & 0,99 \\
\hline $\begin{array}{l}\text { Operational } \\
\text { performance }\end{array}$ & $16,56^{\star}$ & 0,86 & $64 \%$ & 0,097 & 0,99 & 0,97 \\
\hline $\begin{array}{l}\text { Business } \\
\text { performance }\end{array}$ & $17,86^{\star}$ & 0,93 & $78 \%$ & 0,095 & 0,98 & 0,98 \\
\hline
\end{tabular}

${ }^{*} p>0,05$

\section{Results}

The control for the verification of hypotheses $1 \mathrm{a}, 1 \mathrm{~b}$, $1 c$ and $2 a, 2 b, 2 c$ was conducted with the use of the "Structural Equation Modeling Technique", while hypothesis 3 was examined with the use of correlation analysis.

The estimation of the structural model was conducted with the Maximum Likelhood Estimation method, which is the most widespread method of estimation (Kelloway, 1998). The Covariance Matrix was used as the table of entry, because the control of the hypotheses in the Structural Equation Modeling Technique is based on the hypothesis that the matrix that will be analyzed is the Covariance Matrix. Finally, the extraction of the Standardized Completely Solution was requested from the statistical program (LISREL 8.74).

To evaluate the fit of the overall model the chisquare value $\left(X^{2}=634,19\right.$ with 337 degrees of freedom), the $p$-value $(p=0,04120)$, the "Normed- $X^{2 \prime}$ index $(1,88)$, the RSMEA index $(0,091)$ the CFI $(0,93)$ and the GFI
$(0,92)$ were estimated. These values indicate a good fit of the data to the overall model.

For testing of the measurement model the significance of the factor loadings, the construct reliability and the variance extracted were estimated. Results indicated that all loadings are significant at the $\mathrm{p}<0,05$ level. Additionally, the construct reliability and the variance extracted measures for all constructs were satisfactory. Table 4 presents the results for hypotheses 1 and 2.

Results presented below offer full support to hypotheses 1a, 1b, 1c and 2a, 2b, 2c, while at the same time the correlation analysis that was conducted provided support for hypothesis 3 . More specifically, all correlation indexes between independent variables (supplier integration, internal integration, customer integration) were found positive and statistically significant $(p<0,01)$.

An important observation that could be drawn from examining the value of the total effect of the exogenous (independent) to the endogenous (dependent) variables has to do with the hierarchy of their impact. According to the empirical data, customer integration has the larger impact on business performance and internal integration the larger impact on operational performance. The second finding has never been examined and verified by any other quantitative empirical study, but it has only been mentioned to theoretical texts and supported by qualitative surveys (Fawcett and Magnan, 2002). This finding means that one standard deviation change in customer integration leads to a larger impact on operational performance (0,394 standard deviation change) than one standard deviation change in supplier integration $(0,382)$ and customer integration $(0,193)$.

Table 4. Hypotheses $1 \mathrm{a}, 1 \mathrm{~b}, 1 \mathrm{c}$ and $2 \mathrm{a}, 2 \mathrm{~b}, 2 \mathrm{c}$

\begin{tabular}{|c|c|c|c|c|c|c|}
\hline \multirow{2}{*}{$\begin{array}{c}\text { Exogenous } \\
\text { Constructs }\end{array}$} & \multicolumn{5}{|c|}{ Ondogenous Constructs } \\
\cline { 2 - 7 } & Total effect & $\mathrm{t}$-value & Result & Total effect & $\mathrm{t}$-value & Result \\
\hline Supplier integration & 0,382 & 2,31 & H1a Supported & 0,264 & 1,99 & H2a Supported \\
Internal integration & 0,394 & 2,31 & H1b Supported & 0,256 & 2,48 & H2b Supported \\
Customer integration & 0,193 & 3,12 & H1c Supported & 0,396 & 2,33 & H2c Supported \\
\hline
\end{tabular}


The above results underline the importance of supply chain integration on business success and, moreover, support that supply chain integration can only be fully measured when taking into consideration both internal and external measures. A company that successfully implements such an integration plan may be defined as having achieved " $360^{\circ}$ supply chain integration".

\section{Conclusions}

The present study proposed a model about how companies could realistically pursue integration with multiple trading partners (both downwards and upwards). Moreover, cross-functional integration was investigated as a factor that should not be left out from supply chain management initiatives. The proposed model is based on the notion that strong internal and external relationships would improve the performance of manufacturing companies.

The model that was developed has a satisfactory predictive power, indicating that " $360^{\circ}$ supply chain integration" provides significant strategic leverage to implementing companies. Given the intensive competition on the manufacturing sector, such an explanatory power is significant to all firms and the underestimation of its importance would not be wise for most organisations.

The present study suggests that companies will best serve their interests when they are focusing on customer relationships, on building strategies to ensure the involvement of suppliers to the production activity and, on the same time, create certain structures towards enhancing internal communication, knowledge dissemination and crossfunctional integration.

The importance of this three-step balanced approach is, moreover, highlighted by the support for hypothesis 3 , suggesting that a high correlation exists between supplier integration, internal integration and customer integration. Therefore, supply chain integration should be approached in a holistic manner (thus the term " $360^{\circ}$ supply chain integration") with the parallel development of an organisational culture that will move beyond present beliefs about simplistic dyadic supply chain relationships (only with supplies, only with customers or, only, cross-functional). When taking under consideration the significant impact of all three independent variables on business success, one, could furthermore appreciate the value of a balanced " $360^{\circ}$ supply chain integration": focusing only on customer relationships would be profitable, but not as profitable as integrating with all three entities of the supple chain (suppliers, customers and crossfunctional entities).

The present study has significant practical implications, since it provides a decision making framework for manufacturing companies. The statistical validation of the proposed framework can guide practitioners by pointing out areas of attention. The items used to measure the three independent variables can provide confidence to practitioners when it comes to implementing collaborative relationships downwards and upwards and building strong crossfunctional ties.

\section{References}

Anderson, D.L. and Lee, H., (1999), Synchronised supply chains: the new frontier, Achieving Supply Chain Excellence Through Technology, Montgomery Research Inc, San Francisco, CA, pp. 112-121.

Andraski, J.C., (1998), Leadership and the realization of supply chain collaboration, Journal of Business Logistics, 19 (2), pp. 9-11.

Anthony, T., (2000), Supply chain collaboration: success in the new internet economy, Achieving Supply Chain Excellence through Technology, Montgomery Research Inc, San Francisco, CA, pp. 241-244.

Barratt, M., and Oliveira, A., (2001), Exploring the experience of collaborative planning initiatives, International Journal of Physical Distribution \& Logistics Management, 31 (4), pp. 266-289.

Beamon, B.M., (1999), Measuring supply chain performance, International Journal of Operations $\mathcal{E}$ Production Management, 19 (3), pp. 275-292.

Bowersox, D.J., (1969), Physical distribution development, current status and potential, Journal of Marketing, 33 (January), pp. 63-70.

Bowersox, D.J., Closs, D.J., and Stank, T.P., (2000), Ten megatrends that will revolutionize supply chain logistics, Journal of Business Logistics, 21 (2), pp. 1-16.

Burt, D.N., Dobler, D.W., and Starling, S.L., (2003), World Class Supply Management, McGraw-Hill Irwin, Boston, MA.

Carr, A.S., and Pearson, J.N., (1999), Strategically managed buyer-supplier relationships and performance outcomes, Journal of Operations Management, 17 (5), pp. 497-519. 
Cetindamar, D., Catay, B., and Basmaci, O.S., (2005), Competition through collaboration: insights from an initiative in the Turkish textile supply chain, Supply Chain Management: an International Journal, 10 (4)., pp. 238-240.

Chen, Y.F., Drezner, Z., Ryan J.K., and Simchi-Levi, D., (2000), Quantifying the Bullwhip Effect in a Simple Supply Chain: The Impact of Forecasting Lead Times and Information, Management Science, 46, pp. 436-443.

Claro, D.P., Hagelaar, G., and Omta, O., (2003), The determinants of relational governance and performance: how to manage business relationships?, Industrial Marketing Management, 32 (8), pp. 703-716.

El Sawy, O.A., Malhotra, A., Gosain, S., and Young, K.M., (1999), IT-intensive value innovation in the electronic economy: insights from Marshall Industries, MIS Quarterly, 23 (3), pp. 305-335.

Fawcett, S.E., and Magnan, G.M., (2002), The rhetoric and reality of supply chain integration, International Journal of Physical Distribution E Logistics Management, 32 (5), pp. 339-361.

Forrester, J.W., (1961), Industrial Dynamics, MIT Press, Cambridge, MA.

Frohlich, M.T., and Westbrook, R., (2001), Arcs of integration: an international study of supply chain strategies, Journal of Operations Management, 19, pp. 185-200.

Galbraith, J., (1977), Organization Design, Addison-Wesley, Reading, MA.

Garcia-Dastugue, S.J., and Lambert, D.M., (2003), Internet enabled coordination in the supply chain, Industrial Marketing Management, 32 (3), pp. 251-263.

Handfield, B.R., and Nichols, E.L., (2002), Supply Chain Redesign: Transforming Supply Chains into Integrated Value Systems, Prentice-Hall, Englewood Cliffs, NJ.

Handfield, R.B., and Nichols, E.L., (1999), Introduction to Supply Chain Management, Prentice-Hall, Upper Saddle River, NJ.

Heikkila, J., (2002), From supply to demand management: efficiency and customer satisfaction, Journal of Operations Management, 20 (6), pp. 747-767.

Heiman, B., and Nickerson, J.A., (2002), Towards reconciling transaction cost economics and the knowledge-based view of the firm: the context of interfirm collaborations, International Journal of the Economics of Business, 9 (1), pp. 97-116.

Holmstrom, J., Framling, K., Kaipia, R., and Saranen, J., (2002), Collaborative planning forecasting and replenishment, Supply Chain Management: an International Journal, 7 (3), pp. 136-145.

Holweg, M., Disney, S., Holmstrom, J., and Smaros, J., (2005), Supply chain collaboration: making sense of the strategy continuum, European Management Journal, 23 (2), pp. 170-181.
Horvath, L., (2001), Collaboration: the key to value creation in supply chain management, Supply Chain Management: an International Journal, 6 (5), pp. 205-207.

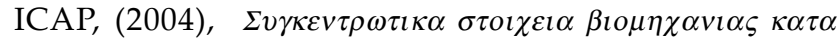

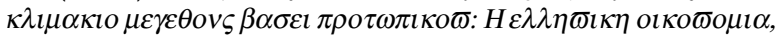
$A \theta \eta v \alpha$ (in Greek language).

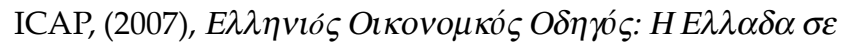
$\alpha \rho \theta \mu о \varpi \varsigma$, Accessed in 5-7-2008 from: www.financialdirectory.gr (in Greek language).

Jayaram, J., and Vickery, S.K., (1998), Supply-based strategies, human resource initiatives, procurement lead-time, and firm performance, International Journal of Purchasing and Materials Management, Winter, pp. 12-23.

Kaplan, R.S., and Norton, D.P., (1992), The Balanced Scorecard: Measures that Drive Performance, Harvard Business Review, 70 (1), pp. 71-79.

Kaufman, A., Wood, C.H., and Theyel, G., (2000), Collaboration and technology linkages: a strategic supplier typology, Strategic Management Journal, 21 (6), pp. 649-663.

Kelloway, K., (1998), Using LISREL for Structural Equation Modeling: A Researcher's Guide, SAGE Publications, London.

Landry, J.T., (2003), The Wal-Mart decade: how a new generation of leaders turned Sam Walton's legacy into the world's \#1 company, Harvard Business Review, 81 (6), pp. 1-24.

Magretta, J., and Dell, M., (1998), The power of virtual integration: an interview with Dell Computers' Michael Dell, Harvard Business Review, 76 (March-April), pp. 72-84.

Mendelson, H., and Pillai, R., (1999), Industry clockspeed: measurement and operational implications, Manufacturing and Service Operations Management, 1 (1), pp. 1-20.

Mentzer, J.T., DeWitt, W., Keebler, J.S., Min, S., Nix, N.W., Smith, C.D., and Zacharia, Z.G., (2001), Defining supply chain management, Journal of Business Logistics, 22 (2), pp. 1-25.

Myhr, N., and Spekman, R.E., (2005), Collaborative supply chain partnerships built upon trust and electronically mediated exchange, Journal of Business $\mathcal{E}$ Industrial Marketing, $20(4,5)$, pp. 179-186.

Narasimhan, R., and Kim, S.W., (2002), Effect of supply chain integration on the relationship between diversification and performance: evidence from Japanese and Korean firms, Journal of Operations Management, 20, pp. 303-323.

National Research Council, (2000), Surviving Supply Chain Integration: Strategies for Small Manufacturers, National Academy Press, Washington, DC.

Pramatari, K., (2007), Collaborative supply chain practices and evolving technological approaches, Supply Chain Management: an International Journal, 12 (3), pp. 210-220. 
Ragatz, G., Handfield, R., and Scannell, T., (1997), Success factors for integrating suppliers into new product development, Journal of Production and Innovation Management, 14 (3), pp. 190-202.

Rosenzweig, E., Roth, A., and Dean, J., (2003), The influence of an integration strategy on competitive capabilities and business performance: An exploratory study of consumer products manufacturers, Journal of Operations Management, 21, pp. 437-456.

Sabath, R., and Whipple, J.M., (2004), Using the customer / product action matrix to enhance internal collaboration, Journal of Business Logistics, 25 (2), pp. 1-19.

Sanders, N.R., and Premus, R., (2005), Modelling the relationship between firm IT capability, collaboration and performance", Journal of Business Logistics, 26 (1), pp. 1-23.

Singh, PJ., and Power, D., (2009), The nature and effectiveness of collaboration between firms, their customers and suppliers: a supply chain perspective, Supply Chain Management: An International Journal, 14 (3), pp. 189-200.

Stank, T.P., Keller, S.B., and Daugherty, P.J., (2001), Supply chain collaboration and logistical service performance, Journal of Business Logistics, 22 (1), pp. 29-48.

Stevens, G., (1989), Integrating the supply chain, International Journal of Physical Distribution and Materials Management, 19 (8), pp. 3-8.

Swink, M., Narasimhan, R., and Kim, S.W., (2002), Manufacturing Practices and Strategic Goal Integration: Effects on Leanness, Agility, and Marketbased Performance, Proceedings of the 2002 National DSI Conference, San Diego, US.
Themistocleous, M., Irani, Z., and Love, P.E.D., (2004), Evaluating the integration of supply chain information systems: a case study, European Journal of Operational Research, 159 (2), pp. 393-405.

Trent, R.J., and Monczka, R.M., (1998), Purchasing and supply management: trends and changes throughout the 1990s, International Journal of Purchasing and Materials Management, Fall, pp. 2-11.

Vickery, S.K., Jayaram, J., Droge, C., and Calantone, R., (2003), The effects of an integrative supply chain strategy on customer service and financial performance: an analysis of direct versus indirect relationships, Journal of Operations Management, 21 (5), pp. 523-539.

Williams, T., Maull, R., and Ellis, B., (2002), Demand chain management theory: constraints and development from global aerospace supply webs, Journal of Operations Management, 20 (6), pp. 691-706.

Williamson, O.E., (1981), The Economics of Organization: The Transaction Cost Approach, The American Journal of Sociology, 87 (3), pp. 548-577.

Williamson, O.E., (1991), Comparative economic organization: the analysis of discrete structural alternatives, Administrative Science Quarterly, 36, pp. 269-296.

Wisner, J.D., (2003), A structural equation model of supply chain management strategies and firm performance, Journal of Business Logistics, 24 (1), pp. 1-25.

Yao, Y., Evers, P.T., and Dresner, M.E., (2007), Supply chain integration in vendor-managed inventory, Decision Support Systems, 43, pp. 663-674.

Mr. Dimitrios Chatzoudes is a PhD Candidate at the Department of Production and Management Engineering of Democritus University of Thrace, Xanthi, Greece. His bachelor Degree is on Business Administration and his Postgraduate Degree on International Economics. His academic interests include Research Methods, International Economics and Production Management. Currently he is a part-time lecturer in the Departments of Business Administration and Accountancy of the Technological Educational Institute (T.E.I.) of Kavala. He teaches Research Methodology. His work has been published in the proceedings of various National and International Conferences and in various International Journals (Journal of Intellectual Capital, International Journal of Business policy and Economics, Practical Issues in Management \& Economics - An International Journal).

Dr. Prodromos Chatzoglou is a Professor of MIS and Business Decisions in the Department of Production and Management Engineering, Democritus University of Thrace, Xanthi, Greece. He received a Bachelor of Arts (BA) in Economics from the Graduate Industrial School of Thessaloniki, Greece, a Master of Science (MSc) in Management Sciences, and a Doctor of Philosophy (PhD) in Information Engineering both from UMIST, Manchester, UK. His research interests include Information Systems (IS) Project Management, Knowledge Management, E-Business, IS Economics, Health Economics, Strategic Management and Business Performance. His work has been published in the Information Systems Journal, Decision Sciences, European Journal of Information Systems, International Journal of Medical Informatics, International Journal of Project Management, Information and Software Technology Journal, among others. He serves as a reviewer and member of the scientific committee of several international journals. 